\title{
Does advertisement call variation coincide with genetic variation in the genetically diverse frog taxon currently known as Leptodactylus fuscus (Amphibia: Leptodactylidae)?
}

\author{
W. RONALD HEYER ${ }^{1}$ and YANA R. REID ${ }^{2}$ \\ ${ }^{1}$ Department of Systematic Biology, National Museum of Natural History, Smithsonian Institution \\ Washington, D.C. 20560-0162 USA \\ ${ }^{2}$ Haskell Indian Nations University, Lawrence, KS 66044 USA
}

Manuscript received on June 18, 2002; accepted for publication on November 27, 2002; contributed by WiLliam Ronald HeYeR*

\begin{abstract}
The frog Leptodactylus fuscus is found throughout much of South America in open and disturbed habitats. Previous study of genetic differentiation in L. fuscus demonstrated that there was lack of genetic exchange among population units consistent with multiple species, rather than a single species. We examine advertisement vocalizations of $L$. fuscus to determine whether call variation coincides with genetic differentiation. Calls were analyzed for 32 individual frogs from 25 localities throughout the distributional range of $L$. fuscus. Although there is variation in calls among geographic samples, call variation is not concordant with genetic variation or geographic distance and the call variation observed is less than that typically found among other closely related species of Leptodactylus. This study is an example of the rare pattern of strong genetic differentiation unaccompanied by salient differences in advertisement calls. The relative infrequency of this pattern as currently understood may only reflect the lack of detailed analyses of genetic and acoustic differentiation within population systems currently understood as single species with substantial geographic distributions.
\end{abstract}

Key words: advertisement calls, Leptodactylus fuscus, speciation.

\section{INTRODUCTION}

Many species of frogs once thought to consist of single species with broad geographic distributions have been found to be comprised of two or more species. Two sources of information have been most critical in reassessing species limits in frogs: molecular and advertisement call data. For example, Toda et al. (1998) concluded that genetic divergences within Rana limnocharis were of such a magnitude that several morphologically indistinguishable species were

*Member of Academia Brasileira de Ciências

Correspondence to: W. Ronald Heyer

E-mail: heyer.ron@nmnh.si.edu hiding within the taxon. Most advertisement vocalizations are species-specific (Gerhardt 1988), and it has been shown that the calls of several species differ by such a magnitude that they serve as premating species isolating mechanisms, yet the morphologies of the frogs are indistinguishable (e.g., Heyer et al. 1996). Within-species advertisement call variation correlates with both temperature and size of calling frog (Duellman and Trueb 1986). Correlation of call parameters with body size is population or species and parameter specific (e.g., Davies and Halliday 1978, Ryan 1980, Zweifel 1968).

Until recently, Leptodactylus fuscus was con- 
sidered to be a single species based on morphological and limited advertisement call data (Heyer 1978) with a distribution ranging from Panama and Colombia east of the Andes to Argentina and on the islands of Margarita, Trinidad, and Tobago. A more recent molecular study estimated genetic differentiation in the species from throughout its geographic range and demonstrated lack of genetic cohesion to such a degree that $L$. fuscus likely is composed of several species (Wynn and Heyer 2001). The purpose of our study is to evaluate geographic variation in advertisement calls of $\mathrm{L}$. fuscus to determine whether there is correlation of advertisement calls with genetic differentiation.

\section{MATERIALS AND METHODS}

Our study relies on analysis of available recordings rather than advertisement calls along transects between population units known to be genetically differentiated from one another. We were able to obtain recordings throughout the geographic range of the species (Fig. 1, Appendix I). A number of the recordings lack associated voucher specimens. Calling Leptodactylus fuscus are usually difficult to capture after they have been recorded. We have only utilized unvouchered recordings that meet at least two of the following requirements: (1) the recordists were experienced neotropical herpetologists who were confident that the species identification was correct; (2) the recordists collected representative specimens of all Leptodactylus from the site, thus providing proxy vouchers; and (3) WRH's evaluation that the calls were correctly identified, based on his comparative experience with calls of the Leptodactylus fuscus group.

Based on the kind of advertisement calls produced by Leptodactylus fuscus and what is known about signal processing in anurans in general (Fritzsch et al. 1988, Gerhardt 1988, Gerhardt and Schwartz 2001, Littlejohn 2001, and Walkowiak 1988), we chose call parameters that would most likely encode species-specific information. The call parameters analyzed are: call rate, call duration, dominant frequency, beginning frequency, ending frequency, frequency sweep, and amplitude features of the waveform (terminology follows Duellman and Trueb 1986 and Heyer et al. 1990).

Canary 1.2 software (Charif et al. 1995) was used to capture calls for analysis at a sample rate of $22050 \mathrm{~Hz}$, and sample size of 16 bits. When available, ten calls per individual were sampled and saved into two files of five calls each due to computer limitations of file size analytic capability. Recordings that had significant signal below and above the frog calls (determined visually from audiospectrogram displays) were filtered around the frog call frequencies before taking data from the calls.

The wave form display was used to measure call rate and call duration. Call duration was difficult to determine precisely in several of the recordings due to background noise in the broadcast channel of the frog call. Questionable beginnings and endings of calls were selected and listened to as a way of determining whether the selected portion was a part of the call or not. The end of the call was more difficult to ascertain than the beginning in these cases. Additionally, in several recordings the end of the call tailed off in such a way that it was difficult to determine whether the tailing off portion was an artifact of the software program or a real signal from the frog. We are confident that call durations are consistent within calls analyzed from a single frog. We are less confident that durations are consistent among frogs, especially when comparing results from clean and noisy recordings. For example, a particularly clean recording from Trinidad (Fig. 2a) suggests that the tail end of the call with reduced intensity has several pulses and is part of the call. In this call, the quieter tail end has a duration of $85 \mathrm{~ms}$ of the total $300 \mathrm{~ms}$ duration of the entire call. Thus, we may be underestimating call duration by as much as $85 \mathrm{~ms}$ for data taken from noisy recordings.

Spectrum analyses were used to determine dominant frequency with the following settings: filter bandwidth $349.70 \mathrm{~Hz}$, frame length 256 points, grid resolution 128 points, overlap 50\%, frequency $86.13 \mathrm{~Hz}$, FFT size 256 points; window 


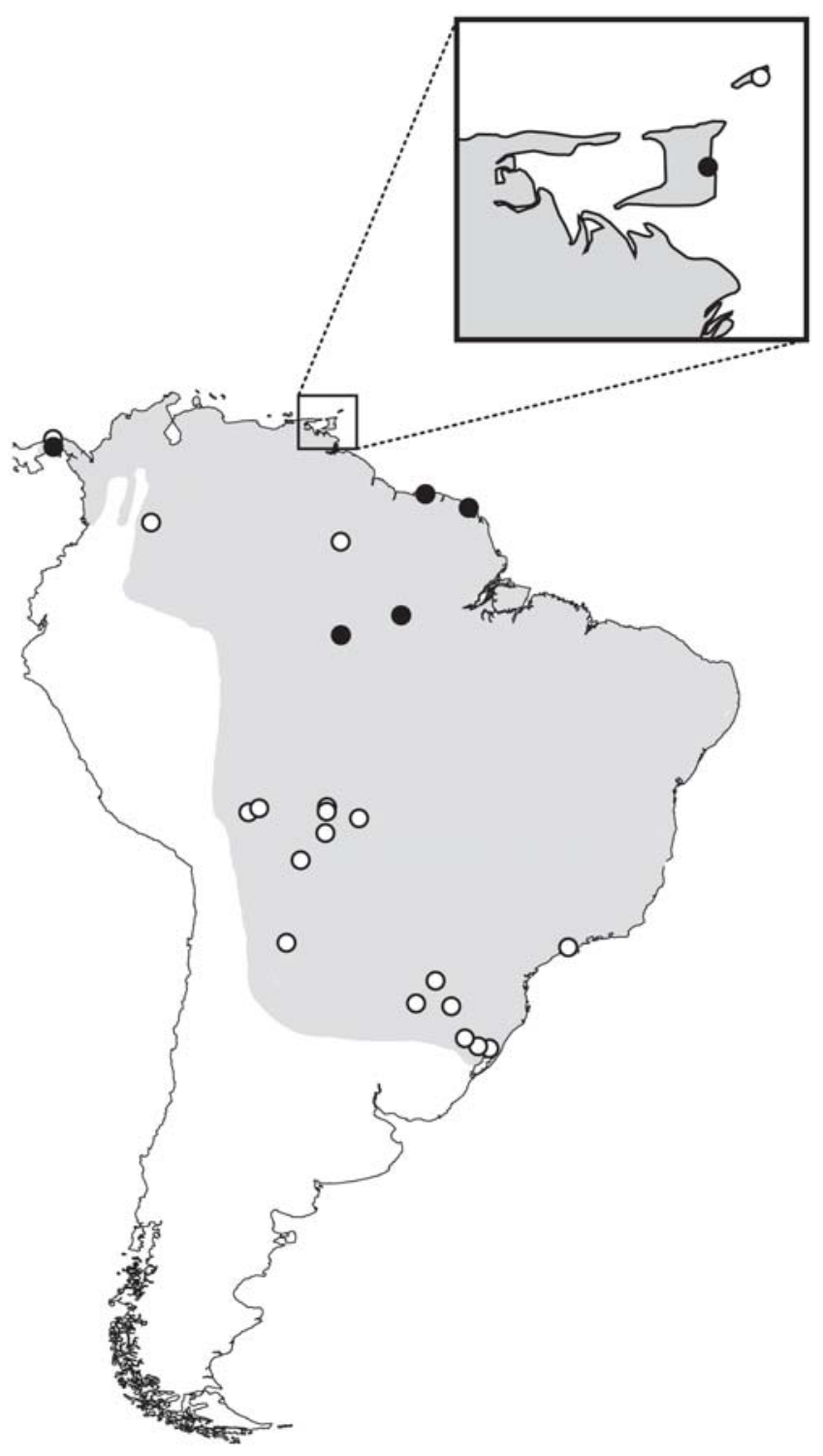

Fig. 1 - Distribution of Leptodactylus fuscus (shaded area) and sites where recordings were made. Open symbols with temperature data; closed symbols lack associated temperature data.

function hamming; amplitude logarithmic; clipping level $-79.79 \mathrm{~dB}$.

Beginning and ending frequencies were taken from audiospectrograms with the following default settings: filter bandwidth $349.70 \mathrm{~Hz}$, frame length 256 points, grid resolution $5.805 \mathrm{~ms}$, overlap 50\%, frequency $86.13 \mathrm{~Hz}$, FFT size 256 points, window function hamming, amplitude logarithmic; clipping level $-80 \mathrm{~dB}$. Frequency sweep is defined as the difference between the ending and beginning frequencies.

Analysis of amplitude variation and harmonic structure of calls was qualitative; the calls were compared visually using printouts of wave forms and audiospectrograms.

Temperature correlations were explored using 

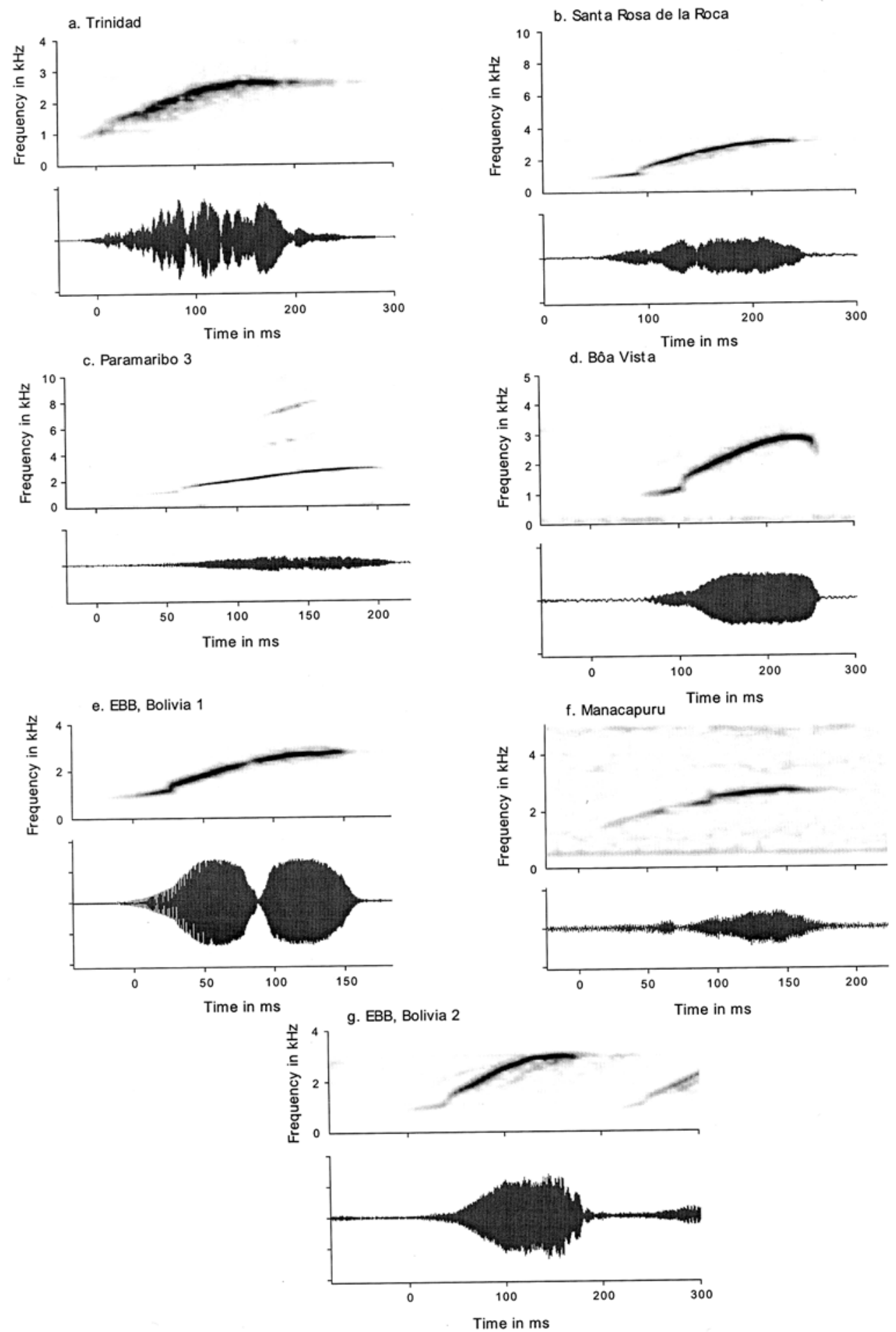

Fig. 2 - Audiospectrogram and wave form of the advertisement call of Leptodactylus fuscus from (a) Trinidad, (b) Santa Rosa de la Roca, Bolivia, (c) Paramaribo, Suriname, recording of frog 3, (d) Boa Vista, Brazil, (e) Estación Biologica del Beni, Bolivia, S. Reichle recording of frog 1, (f) Manacapuru, Brazil, (g) Estación Biologica del Beni, S. Reichle recording of frog 2. 
TABLE I

Regression formulae of quantitative call parameters of Leptodactylus fuscus with temperature.

\begin{tabular}{l|c|c}
\hline Parameter & Regression formula & $\begin{array}{c}\text { Significance } \\
(\mathrm{p} \text {-value })\end{array}$ \\
\hline Call rate/min & $\mathrm{y}=-46.919+3.895 \mathrm{x}$ & 0.021 \\
Duration(s) & $\mathrm{y}=0.426-0.009 \mathrm{x}$ & 0.015 \\
Dominant frequency & $\mathrm{y}=988.495+58.687 \mathrm{x}$ & 0.013 \\
Beginning frequency & $\mathrm{y}=1087.907-5.464 \mathrm{x}$ & 0.344 \\
Ending frequency & $\mathrm{y}=1403.247+46.051 \mathrm{x}$ & 0.018 \\
Frequency sweep & $\mathrm{y}=320.163+51.275 \mathrm{x}$ & 0.007 \\
\hline
\end{tabular}

two stage least squares regression analyses in the statistical program SYSTAT10 (Anonymous, 2000). Two stage least squares regression was used as some of the temperatures were based on estimates (the recordist lacked a thermometer but gave an estimate for the temperature). All parameters that were significantly correlated with temperature were standardized to $25^{\circ} \mathrm{C}$ before further analyses. Standardization was achieved by using the y intercept and slope information from the two stage least squares regression analyses (Table I).

There were insufficient recordings with voucher specimens to adequately explore relationships between male size and call parameters (see discussion).

Temperature adjusted call data were analyzed with multidimensional scaling in SYSTAT10 using Kruskal's loss function with the log option (Wilkinson 2000). The distance matrix used was standardized Euclidean distances based on mean parameter values for each individual. The Euclidean distance matrix was produced using SYSTAT10 (Wilkinson et al. 2000). As we have six quantitative parameters in our study, we examined our data using two dimensions. Multidimensional scaling was chosen, in part, so that the results of this study could be compared with the genetic results (Wynn and Heyer 2001).

To explore if there is a correlation of geo- graphic distance with call differentiation, we used a map distance matrix and the standardized Euclidean distance matrix used in the multidimensional scaling analysis. Geographic distances are linear map distances in kilometers. The Mantel test is used to determine whether the matrices being compared are statistically significant, using NTSYSpc version 2.02 (Rohlf 1998) with the raw Mantel statistic option with 1000 permutations.

\section{RESULTS}

All calls analyzed share the following features: the call is variously amplitude modulated and is frequency modulated to produce a rising whistle.

\section{HaRmonic Structure}

Several of the recordings can not be evaluated for harmonic structure due to the quality of the recordings. Some calls lack harmonic structure and others have harmonics. There appears to be variation in whether harmonics occur at the beginning of the call and/or in the body of the call (Figs. 2b, 2c). Variation in presence and absence of harmonics occurs among individuals from the same localities at Paramaribo, Suriname and Estación Biologica del Beni, Bolivia. Given the nature of the intralocality variation and inability to determine whether harmonics are present or absent in several of the recordings, harmonic structure is not evaluated further herein. 


\section{Temporal Analyses of Calls}

With two exceptions, all calls begin at a lower frequency and rise throughout the call, either with a terminal plateau (Fig. 2a) or not (Fig. 2c). The two exceptions are recordings from Río Pacora, Panama and Boa Vista, Brazil that have a drop in frequency at the end of the call (Fig. 2d).

With few exceptions, calls begin with a distinctive low frequency component that rises very slowly then shifts noticeably in a step-wise fashion to a smoothly rising frequency for the remainder of the call (Figs. 2b-d). Usually there is no temporal break between the initial component and the remainder of the call. There is a very short break in the following samples, which according to the terminology utilized would comprise a distinct initial note: La Jagua, Panama; Santa Cruz de la Sierra, Bolivia; Estación Biologica del Beni, El Porvenir, Bolivia, frog 1; and Embarcación, Argentina. Recordings from Paramaribo, Suriname, frog 3 and Frederico Westfalen, Brazil, frog 1 vary, having initial notes or not. The recordings from Guaíba, Brazil; Frederico Westfalen, Brazil, frog 2; and the two individuals from El Tirol, Paraguay can not be accurately evaluated for this feature.

There is considerable amplitude variation in the rest of the call (excluding the initial pulse/note), ranging from essentially unpulsed (Fig. 2d), weakly partially pulsed, partially pulsed (Fig. 2b), pulsed with some pulses being partially pulsed (Fig. 2a), to two unpulsed notes (Fig. 2e). Samples from French Guiana; 159 km North of Santa Rosa de la Roca, Bolivia; Santa Rosa de la Roca, Bolivia; and Estación Biologica del Beni, El Porvenir, Bolivia, frog 1 have two distinct pulses in the body of the call (Fig. 2b). The recording of the frog from $169 \mathrm{~km}$ North of Santa Rosa de la Roca, Bolivia, had variable calls, ranging from weakly partially pulsed to two distinct pulses, each pulse being partially pulsed. The recordings of the frogs from La Jagua, Panama and near Manacapuru, Brazil have the most distinctive pulse structure of the calls analyzed. The recording from near Manacapuru, Brazil is further distinctive in having a series of frequency steps associated with pulses in the call (Fig. 2f).

\section{Quantitative Parameter Correlations WITH TEMPERATURE}

Beginning frequency is the only quantitative parameter that is not significantly correlated with temperature (adjusted $r^{2}=0.012, p=0.267$ ). Call duration is the only parameter with a statistically significant negative correlation with temperature (adjusted $r^{2}=0.313, p=0.002$ ). The remaining parameters have statistically significant positive correlations with temperature: call rate (adjusted $r^{2}=$ $0.304, p=0.003$ ); dominant frequency (adjusted $\left.r^{2}=0.281, p=0.004\right)$; ending frequency (adjusted $\left.r^{2}=0.274, p=0.004\right)$; and frequency sweep (adjusted $r^{2}=0.334, p=0.001$ ).

\section{INTRASAMPLE VARIATION}

There is relatively little variation among calls given by the same individual. In most of the recordings analyzed, the variation of quantitative parameters for calls made by the same individual is little more than would be expected due to measurement error (e.g., Table II). The greatest variation observed among calls given by the same individual is call rate; the most extreme example is an individual frog from Paramaribo, Suriname with call rates/min of 33 and 70. Call rate comparisons in our data are difficult to evaluate due to several potentially confounding factors. Specifically, call rates are often slower when a frog begins calling than after the frog has been calling for a while. Call rates also vary depending on the individual physiological conditions or the social settings of the males. We have no data to evaluate these confounding factors, but we do not think the other parameters we evaluate are as influenced by these factors as call rate is. Our reasoning is that call rate is the only parameter examined that is entirely behaviorally controlled; all other parameters have a morphologically constrained component to them.

Data for multiple individuals with associated temperature data are available from three localities 


\section{TABLE II}

Summary data for multiple recordings from single localities. All variables except for beginning frequency standardized to $25^{\circ} \mathrm{C}$. Sample IDs are those used in multidimensional scaling analysis ${ }^{1}$.

\begin{tabular}{c|c|c|c|c|c|c|c|c|c|}
\hline \multirow{2}{*}{ Sample ID } & \multicolumn{3}{|c|}{ Call rate/min } & \multicolumn{3}{c|}{ Duration(s) } & \multicolumn{3}{c|}{ Dominant frequency } \\
\cline { 2 - 9 } & Min & Max & Mean & Min & Max & Mean & Min & Max & Mean \\
\hline F1 & 46 & 55 & 50.3 & 0.32 & 0.36 & 0.34 & 2025 & 2085 & 2047 \\
F2 & 36 & 39 & 37.4 & 0.15 & 0.17 & 0.15 & 1859 & 1892 & 1880 \\
L1 & 42 & 50 & 45.5 & 0.17 & 0.19 & 0.18 & 2156 & 2242 & 2326 \\
L2 & 68 & 86 & 77.0 & 0.17 & 0.18 & 0.17 & 1901 & 2247 & 2163 \\
L3 & 72 & 74 & 73.0 & 0.16 & 0.19 & 0.17 & 2158 & 2507 & 2276 \\
L4 & 85 & 88 & 86.7 & 0.16 & 0.17 & 0.16 & 2699 & 2784 & 2712 \\
L5 & 91 & 92 & 91.1 & 0.18 & 0.19 & 0.18 & 2859 & 2866 & 2862 \\
Q1 & 46 & 56 & 50.9 & 0.18 & 0.22 & 0.21 & 2824 & 2914 & 2840 \\
Q2 & 61 & 62 & 61.4 & 0.18 & 0.21 & 0.19 & 2662 & 2918 & 2842 \\
\hline \hline Sample ID & Beginning frequency & Ending frequency & Frequency sweep \\
\cline { 2 - 10 } & Min & Max & Mean & Min & Max & Mean & Min & Max & Mean \\
\hline F1 & 800 & 890 & 849 & 2050 & 2182 & 2129 & 1167 & 1379 & 1278 \\
F2 & 990 & 1040 & 1021 & 2038 & 2188 & 2112 & 1031 & 1211 & 1084 \\
L1 & 860 & 920 & 900 & 2229 & 2399 & 2326 & 1289 & 1459 & 1406 \\
L2 & 800 & 866 & 833 & 2249 & 2389 & 2283 & 1376 & 1509 & 1430 \\
L3 & 900 & 1000 & 944 & 2449 & 2609 & 2522 & 1469 & 1649 & 1558 \\
L4 & 950 & 1000 & 965 & 2708 & 2858 & 2779 & 1770 & 1860 & 1816 \\
L5 & 900 & 1020 & 971 & 2885 & 2955 & 2924 & 1884 & 1980 & 1948 \\
Q1 & 910 & 1023 & 958 & 2823 & 2883 & 2858 & 1872 & 1993 & 1940 \\
Q2 & 960 & 1360 & 1174 & 2773 & 3023 & 2913 & 1643 & 2033 & 1794 \\
\hline
\end{tabular}

1. F1 - Brazil, Frederico Westfalen, recording of frog 2; F2 - Brazil, Frederico Westfalen, recording of frog 1; L1 - Bolivia, Estación Biologica del Beni (EBB), El Porvenir, recording of frog 2; L2 - Bolivia, EBB, El Porvenir, recording of frog 1; L3 - Bolivia, EBB, El Porvenir, recording of frog 3; L4 - Bolivia, EBB, recording of frog 1, December 1994; L5 - Bolivia, EBB, recording of frog 2, 6 November 1994; Q1 - Paraguay, E1 Tirol, recording of frog 2; Q2 - Paraguay, E1 Tirol, recording of frog 1.

(for this purpose, the two sites within the Estación Biologica del Beni are considered to represent a single locality). The intra-individual variation is about equal to inter-individual variation in the two samples from El Tirol, Paraguay (Table II, Q1 and Q2). In contrast, inter-individual variation is noticeably greater than intra-individual variation for the samples from Frederico Westfalen, Brazil and Estación Biologica del Beni, Bolivia (Table II, F1 versus F2 and samples L1-L3 versus L4-L5 respectively). Although the variation is considerable among certain individuals from the same localities, the magnitude of differences are within those predicted to still be perceived by single individual frogs (e.g., the data in Zakon and Wilczynski 1988 indicate a minimum range of around $200-400 \mathrm{~Hz}$ beyond which frogs can distinguish frequencies). 


\section{INTERSAMPLE VARIATION}

Amplitude modulation can be modified by environmental parameters (Gerhardt 1994), which is likely one reason that most frogs call frequently to overcome the signal distortion caused by the biotic and abiotic environment from the signal sender to the signal receiver. Ideally, amplitude modulation should be evaluated from recordings made at similar $\mathrm{dB}$ levels, recorded the same distances from the calling frog. Our recordings were not made under standardized conditions. Nevertheless, the kind of variation observed (Fig. 2) suggests to us that there is biologically meaningful variation in amplitude modulation in Leptodactylus fuscus calls throughout its geographic range. However, none of the calls can be grouped so that the groups differ by the same magnitude as found between other members of the Leptodactylus fuscus species group (e.g., the clearly pulsed versus non-pulsed calls of the sibling species pair Leptodactylus mystaceus and L. didymus, Heyer et al. 1996). The most striking difference in the calls analyzed is the single versus two note calls from two individuals from the same locality recorded by $\mathrm{S}$. Reichle from Bolivia (Fig. 2e and g). Other calls from the same site are variously intermediate in amplitude patterns, however, indicating the differences reflect individual variation rather than population or species level differentiation.

As indicated in the Materials and Methods section, the call rate data may have a larger component of variability due to male condition and social setting than the other quantitative variables analyzed. Multidimensional scaling analyses were performed including and excluding the call rate data in Table III. The results are almost identical, with the only difference in relative positions being a switch of samples A and L3 as shown in Figure 3. Consequently, the analysis including call rate data is used to explore variation of the quantitative call variables. For the multidimensional scaling analysis using all variables, there were 29 iterations smoothly reaching a final configuration of 0.140 and a proportion of variance $\left(r^{2}\right)$ of 0.92 .
Quantitative data for multiple frogs from the same localities would be expected to appear as nearest neighbors in a multidimensional scaling analysis, assuming the multiple samples from single sites are conspecific.

The calls of the two frogs from the same Paraguay locality (Q1, Q2) are not each other's closest neighbors (Fig. 3). The call data for one frog from the same locality in Rio Grande do Sul, Brazil (F1) is nearer to the sample point from a different locality in Rio Grande do Sul (G) than to the second same-locality data (F2) (Fig. 3). The call data for five frogs from the Estación Biologica del Beni, Bolivia (L1-L5, shaded symbols) together encompass almost one-half the total multidimensional scaling space variation. Samples L1-L2 and L4-L5 are near neighbors but these sample pairs are quite distant from each other, with L3 being closer to L1-L2 than L4-L5 (Fig. 3).

There is little geographic structure in the multidimensional scaling results. All call data from Rio Grande do Sul (F, G, H, I) form a cohesive cluster, but the next closest geographic sample from Iguazú Falls, Argentina (R) is much nearer several other samples than the Rio Grande do Sul samples (Fig. 3). The non-Estación Biologica del Beni call data from Bolivia (M, N, O, P) are each closer to other samples than to either the Estación Biologica del Beni (Fig. 3, shaded symbols) or other Bolivian samples (Fig. 3).

The multidimensional scaling results indicate that the frog call from Boracéia, Brazil (K, Fig. 3) is the most distinct sample in the analysis and that the variation observed in the five frog calls from Estación Biologica del Beni (Fig. 3, shaded symbols) represent either (a) that the advertisement call data within sites are almost as variable as data among all sites, or (b) that there is more than one species at the site. We interpret the available data as signifying that there is a single species at the Estación Biologica del Beni, but this interpretation requires additional data to be conclusively accepted.

The frog from Boracéia was recorded in captivity on the same evening it was captured. How- 


\section{TABLE III}

Mean values for variables taken from recordings with associated temperature data. All variables except for beginning frequency standardized to $25^{\circ} \mathrm{C}$. Sample IDs are those used in multidimensional scaling analyses ${ }^{1}$.

\begin{tabular}{c|c|c|c|c|c|c}
\hline Sample ID & Call rate/min & Duration(s) & $\begin{array}{c}\text { Dominant } \\
\text { frequency }\end{array}$ & $\begin{array}{c}\text { Beginning } \\
\text { frequency }\end{array}$ & $\begin{array}{c}\text { Ending } \\
\text { frequency }\end{array}$ & $\begin{array}{c}\text { Frequency } \\
\text { sweep }\end{array}$ \\
\hline A & 74.1 & 0.18 & 2246 & 993 & 2594 & 1596 \\
B & 60.6 & 0.18 & 2542 & 973 & 2611 & 1642 \\
C & 30.3 & 0.19 & 2318 & 984 & 2496 & 1498 \\
D & 51.5 & 0.15 & 2682 & 1033 & 2783 & 1750 \\
E & 10.2 & 0.21 & 2514 & 915 & 2542 & 1613 \\
F1 & 50.3 & 0.34 & 2047 & 849 & 2129 & 1278 \\
F2 & 37.4 & 0.15 & 1880 & 1021 & 2112 & 1084 \\
G & 30.5 & 0.24 & 2085 & 957 & 2248 & 1311 \\
H & 32.7 & 0.26 & 2110 & 996 & 2350 & 1347 \\
I & 22.6 & 0.27 & 2228 & 940 & 2273 & 1340 \\
J & 44.5 & 0.22 & 2787 & 993 & 2550 & 1549 \\
K & 26.7 & 0.16 & 1638 & 980 & 1732 & 775 \\
L1 & 45.5 & 0.18 & 2203 & 900 & 2326 & 1406 \\
L2 & 77.0 & 0.17 & 2163 & 833 & 2283 & 1430 \\
L3 & 73.0 & 0.17 & 2276 & 944 & 2522 & 1558 \\
L4 & 86.7 & 0.16 & 2712 & 965 & 2779 & 1816 \\
L5 & 91.1 & 0.18 & 2862 & 971 & 2924 & 1948 \\
M & 73.4 & 0.16 & 2622 & 971 & 2606 & 1632 \\
N & 55.8 & 0.20 & 2956 & 985 & 3045 & 2058 \\
O & 14.3 & 0.23 & 2634 & 1014 & 2737 & 1700 \\
P & 33.5 & 0.24 & 2396 & 955 & 2525 & 1550 \\
Q1 & 50.9 & 0.21 & 2840 & 958 & 2858 & 1940 \\
Q2 & 61.4 & 0.19 & 2842 & 1174 & 2913 & 1794 \\
R & 45.6 & 0.25 & 2430 & 901 & 2626 & 1740 \\
S & 62.7 & 0.16 & 2290 & 735 & 2510 & 1793 \\
\hline & & & & & & \\
\hline
\end{tabular}

1. A - Panama, Río Pacora; B - Colombia, near Puerto Lopez; C - Tobago, Roxborough; D - Suriname, Paramaribo, recording of frog 3; E - Brazil, near Pontes e Lacerda; F1 - Brazil, Frederico Westfalen, recording of frog 2; F2 - Brazil, Frederico Westfalen, recording of frog 1; G - Brazil, Guaíba; H - Brazil, Rio Pardinho; I - Brazil, São Jerônimo; J - Brazil, Boa Vista; K - Brazil, Boracéia; L1 - Bolivia, Estación Biologica del Beni (EBB), El Porvenir, recording of frog 2; L2 Bolivia, EBB, El Porvenir, recording of frog 1; L3 - Bolivia, EBB, El Porvenir, recording of frog 3; L4 - Bolivia, EBB, recording of frog 1, December 1994; L5 - Bolivia, EBB, recording of frog 2, 6 November 1994; M - Bolivia, Santa Cruz de la Sierra; N - Bolivia, Santa Rosa de la Roca; O - Bolivia, 159 km N Santa Rosa de la Roca; P - Bolivia, 169 km N Santa Rosa de la Roca; Q1 - Paraguay, El Tirol, recording of frog 2; Q2 - Paraguay, El Tirol, recording of frog 1; R - Argentina, Iguazú; S - Argentina, Embarcación. 


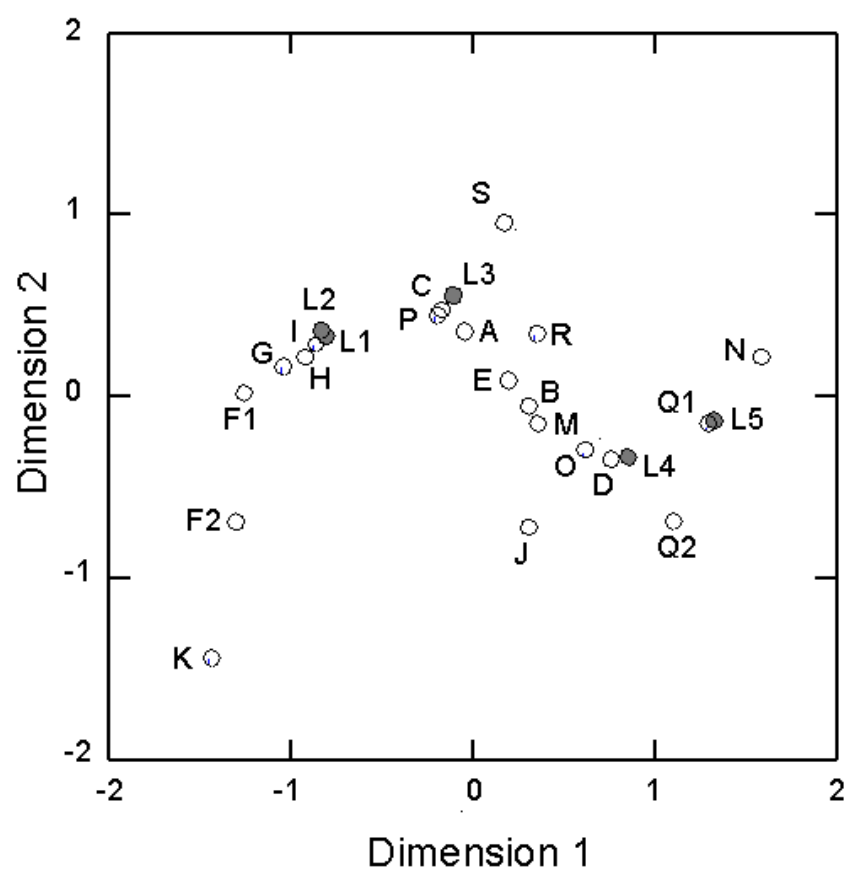

Fig. 3 - Plot of first against second axis of multidimensional scaling data. Shaded symbols represent data for five individuals from a single locality in Bolivia. A - Panama, Río Pacora; B - Colombia, near Puerto Lopez; C - Tobago, Roxborough; D - Suriname, Paramaribo, recording of frog 3; E Brazil, near Pontes e Lacerda; F1 - Brazil, Frederico Westfalen, recording of frog 2; F2 - Brazil, Frederico Westfalen, recording of frog 1; G - Brazil, Guaíba; H - Brazil, Rio Pardinho; I - Brazil, São Jerônimo; J - Brazil, Boa Vista; K - Brazil, Boracéia; L1 - Bolivia, Estación Biologica del Beni (EBB), El Porvenir, recording of frog 2; L2 - Bolivia, EBB, El Porvenir, recording of frog 1; L3 Bolivia, EBB, El Porvenir, recording of frog 3; L4 - Bolivia, EBB, recording of frog 1, December 1994; L5 - Bolivia, EBB, recording of frog 2, 6 November 1994; M - Bolivia, Santa Cruz de la Sierra; N - Bolivia, Santa Rosa de la Roca; O - Bolivia, 159 km N Santa Rosa de la Roca; P - Bolivia, 169 km N Santa Rosa de la Roca; Q1 - Paraguay, El Tirol, recording of frog 2; Q2 - Paraguay, El Tirol, recording of frog 1; R - Argentina, Iguazú; S - Argentina, Embarcación.

ever, the frog called notably sporadically. New field recordings should be obtained from Boracéia to determine whether the available distinctive call is characteristic of the entire Boracéia population or an artifact of animal stress and/or factors related to artificial calling conditions.

The Mantel test comparing the geographic distance and standardized Euclidean call distance matrices is not statistically significant. The Mantel test matrix correlation is $r=-0.02$ and the onetail probability is $p$ [random $\mathrm{Z} \geq$ observed $\mathrm{Z}$ ] = 0.425 .
In sharp contrast to the preceding results, the multidimensional scaling results for the genetic data showed clear geographic structure and there was a significant correlation of geographic distance with genetic distance for the entire data set (Wynn and Heyer, 2001).

\section{DISCUSSION}

\section{CAll - Temperature Interaction}

Call parameter correlations with temperature in Leptodactylus fuscus are the same as in other studies 
with one exception. Duellman and Trueb (1986) indicated that call rates, pulse rates, and frequencies increase with temperature in frogs and that call duration decreases with temperature, although Gerhardt and Schwartz (2001) stated "...typical changes in carrier frequency with temperature in anurans are relatively small...' Our data demonstrate a significant negative correlation with call duration and significant positive correlations for call rate, dominant frequency, ending frequency, and frequency sweep. In all of these significant correlations, which would be predicted from previous studies, temperature accounts for about $30 \%$ of the variation in each call parameter. The exception is that the beginning frequencies of the calls in L. fuscus do not demonstrate a statistically significant correlation with temperature. This suggests that the beginning call frequency is morphologically determined and not affected by temperature. A plausible explanation is that when the laryngeal muscles are relaxed, the mass of the vocal cords in the larynx determines the beginning frequency of the call. The other call frequency parameters we evaluated can be assumed to reflect the action of laryngeal muscles increasing the tension on the vocal cords resulting in rising frequency throughout all or almost all of the rest of the call. Manz (1975) demonstrated a positive correlation between temperature and laryngeal muscle contraction. Thus, beginning frequency appears to be morphologically predetermined in L. fuscus, but the frequency modulation of the call is under the frog's control (firing rate of laryngeal muscles), which has a temperaturedependent component to it.

\section{CALL - Size Interaction}

Although we could not address the relationship between male size and call parameters directly, indirect evidence provides an indication that this relationship is not as strong as the relationship between call parameters and temperature. The moderately large species Bufo viridis demonstrates a strong relationship of fundamental frequency regressed against body size with $r^{2}$ values ranging from 0.25 to 0.47 for different populations (Giacoma and Castellano
2001). However, Leptodactylus fuscus is a smaller species than Bufo viridis, with a relatively small range of adult size (36-48 $\mathrm{mm}$ for almost all 344 males measured throughout the distributional range, Fig. 4) and would be expected not to show the same magnitude of correlation as occurs in Bufo viridis.

\section{Calls and Genetic Divergence Patterns}

A major function of frog advertisement calls is to attract mates. In general, advertisement calls are under stabilizing selection, matching signal and receiver capabilities to promote choosing homogametic mates that will result in successful offspring. This point can not be overemphasized.

The kinds of situations that would lead to evolutionary change in calls include: (a) sexual selection, generally for some trait that females interpret as indicating greater male fitness, such as lower dominant frequency, which indicates larger size (Ryan 1985); (b) a population faced with a change of habitat, such as a forested habitat becoming an open habitat (see discussion in Gerhardt 1994); (c) predator pressure (Gerhardt 1994), which is posited as the reason why many frogs of the genus Eleutherodactylus emit very infrequent calls; and (d) populations that have genetically diverged in isolation coming into contact with each other-if the hybrids are not as fit as the parental populations, selection will result in differentiation of the calls (Littlejohn 1988).

Given what is known about genetic differentiation in Leptodactylus fuscus (Wynn and Heyer 2001) and call differentiation in frogs in general, we would expect the call and genetic differentiation to belong to one of the following two patterns.

Pattern 1. Genetically differentiated units have distinct advertisement calls, often differing by an order of magnitude in some feature of the call. This is the dominant pattern in frogs of the genus Leptodactylus (and frogs in general) and can be treated as the null hypothesis in evaluating the interaction of call and genetic differentiation. An example of a closely related cluster of frogs that have allopatric distributions with distinct advertisement calls is the Leptodactylus mystaceus cluster. Heyer 


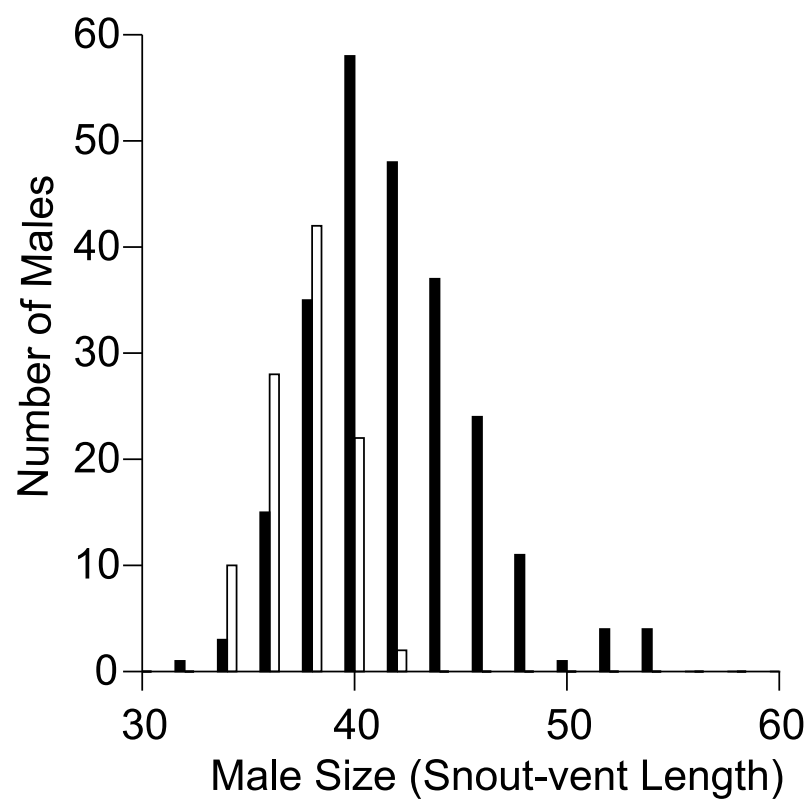

Fig. 4 - Variation in size of adult male Leptodactylus fuscus. Black bars indicate data from localities throughout the geographic range with the exception of adult males from a single locality (Porto Velho, Brazil) indicated by the white bars.

et al. (1996) described distinct advertisement calls for $L$. didymus, elenae, mystaceus, and notoaktites (the call of the other member of the cluster, L. spixi, has yet to be analyzed). Given the L. mystaceus cluster example, we anticipated that $L$. fuscus would fit this pattern.

Pattern 2. Genetically differentiated units have little call differentiation. Within this, there are two subpatterns.

Pattern 2a. Allopatric systems. Genetically differentiated populations are geographically isolated from each other. The genetically isolated populations retain the ancestral advertisement call (through stabilizing selection). This is the most common reported Pattern 2 type, but has been documented in relatively few cases to date (e.g., the Geocrinia rosea complex in southwestern Australia, Driscoll 1998 for genetic data and Roberts and Wardell-Johnson 1995 for call data and the clades of Hyla arenicolor isolated on different sky islands in southwestern USA, Barber 1999a, b).
Pattern 2b. Allopatric or sympatric systems. Small differences in calls are adequate for female discrimination. This is the rarest reported pattern. Blair and Littlejohn (1960) demonstrated that the calls of the chorus frogs Pseudacris ornata and streckeri differ by only a few hundred hertz in carrier frequency, yet females discriminate between the calls of the two species. Based on what is known about hearing discrimination in frogs in general, the difference in carrier frequency in the two chorus frog species would not have been predicted to be sufficient for females to consistently discriminate them.

The data in Wynn and Heyer (2001) were not adequate to delineate genetically isolated sets of populations with geographic precision. However, in order to determine to which of the above two major patterns Leptodactylus fuscus belongs, the following characterization is sufficient. The allozyme data indicate that there is no genetic exchange among populations with high levels of genetic differentiation from Trinidad, southeast Brazil, and Salta, Ar- 
gentina. The genetic data are consistent with treating L. fuscus from these three areas as three distinct species. The calls of L. fuscus from these three areas show relatively little differentiation. The calls do not approach the degree of differentiation found in the members of the allopatrically distributed members of the L. mystaceus complex (Heyer et al. 1996).

The Leptodactylus fuscus data unambiguously do not fit the first pattern and do fit the second. The current data for $L$. fuscus are inadequate to determine whether they represent an example of Pattern 2a or Pattern 2b. In order to determine to which Pattern 2 type L. fuscus conforms, the following types of data need to be gathered.

1) Finer geographic sampling of advertisement calls and genetic data. The advertisement calls must be associated with temperature data and voucher specimens in order to factor out the interactions of calls with temperature and size of calling males if they are statistically significantly correlated.

2) Gravid females need to be tested to determine whether they can discriminate between and among the kinds of relatively small differences observed in the advertisement calls of L. fuscus demonstrated in this paper.

At present, Pattern 2 has been uncommonly reported in frogs. That may be due to the rarity of analyses of both genetic and acoustic differentiation within frogs considered to be a single species that have substantial geographic distributions. As more such species are evaluated genetically and acoustically, we may find that Pattern 2 is more common than currently understood. For example, work on the neotropical frog Physalaemus pustulosus by Ryan et al. (1996) demonstrated that it also fits Pattern 2. Current work with female choice experiments should soon demonstrate whether $P$. pustulosus fits Pattern $2 \mathrm{a}$ or $2 \mathrm{~b}$ (A.S. Rand, pers. comm.).

\section{APPENDIX I}

Recordings of advertisement calls of Leptodactylus fuscus. Temperatures are for air. Mean values used in analyses for each individual frog are based on the number of calls indicated. The localities are organized by countries in a general north to south order. Institutional abbreviations are as listed in Leviton et al. (1985).

Panama: Panama; La Jagua, 95'N, 79²0'W. A.S. Rand recording, 1 May 1969, time not indicated, temperature not indicated, unvouchered, recorded by A. Stanley Rand, 10 calls.

Panama: Panama; Río Pacora where it crosses the Pan American Highway, $9^{\circ} 5^{\prime} \mathrm{N}, 7^{\circ} 17^{\prime}$ W. A.S. Rand recording, 6 July 1994, 18:57h, $26^{\circ} \mathrm{C}$, unvouchered, recorded by A. Stanley Rand, 10 calls.

Colombia: Meta; near Puerto Lopez, 405'N, $72^{\circ} 58^{\prime} \mathrm{W}$. USNM recording 119 , cut 1, 9 April 1971 , time not indicated, $24.4^{\circ} \mathrm{C}$, unvouchered, recorded by William F. Pyburn, 10 calls.

Trinidad: Nariva; Nariva Swamp, $10^{\circ} 25^{\prime} \mathrm{N}$, $61^{\circ} 4$ 'W. Commercial CD recording, "Frogs of Trinidad, Tobago and the Lesser Antilles, a Guide to Their Calls Recorded by Morley Read.' No collection or recording data available, recorded by Morley Read, 10 calls.

Tobago: St. Paul; Roxborough, $11^{\circ} 15^{\prime} \mathrm{N}$, $60^{\circ} 35^{\prime} \mathrm{W}$. USNM recording 220 , cut 1,2 July 1989 , 20:00-21:30 h, $27.8^{\circ} \mathrm{C}$, unvouchered, recorded by Addison Wynn, 10 calls.

Suriname: Paramaribo; Paramaribo, $5^{\circ} 50^{\prime} \mathrm{N}$, $55^{\circ} 10^{\prime}$ W. Frog 1 - M.S. Hoogmoed recording, 1968, time not indicated, temperature not indicated, unvouchered, recorded by Marinus S. Hoogmoed, 4 calls. Frog 2 - M.S. Hoogmoed recording, 13 January 1970, 19:00h, temperature not indicated, unvouchered, recorded by Marinus S. Hoogmoed, 10 calls. Frog 3 - M.S. Hoogmoed recording, 6 January $1975,19: 15 \mathrm{~h}, 25^{\circ} \mathrm{C}$, unvouchered, recorded by Marinus S. Hoogmoed, 10 calls.

French Guiana. Commercial CD recording, "Guide Sonore des Amphibiens Anoures de Guyane', by Christian Marty and Philippe Gaucher. No collection or recording data indicated, 5 calls.

Brazil: Amazonas; near Manacapuru, $3^{\circ} 18^{\prime} \mathrm{S}$, $60^{\circ} 36^{\prime}$ W. M.S. Hoogmoed recording, 25 November $1985,23: 00 \mathrm{~h}$, no temperature indicated, un- 
vouchered, recorded by Marinus S. Hoogmoed, 10 calls.

Brazil: Pará; Rio Nhamunda, Ceu Estrelado, $2^{\circ} 4^{\prime}$ S, 56 $43^{\circ}$ W. M.S. Hoogmoed recording, 30 November 1988, 20:16 h, no temperature indicated, specific caller not associated with the recording, probably either M. Hoogmoed field number MSH 5010 ( 2 males) or field number TCAP 1057 (1 male, 2 females, now at MPEG), recorded by Marinus S. Hoogmoed, 10 calls.

Brazil: Mato Grosso, near Pontes e Lacerda, $15^{\circ} 12^{\prime} \mathrm{S}, 59^{\circ} 22^{\prime} \mathrm{W}$. USNM recording 58 , cut 1,9 December $1985,27.7^{\circ} \mathrm{C}$, unvouchered, recorded by Ronald I. Crombie, 10 calls.

Brazil: Rio Grande do Sul; Frederico Westfalen, $27^{\circ} 22^{\prime}$ S, 53 $24^{\prime}$ W. Frog 1 - A. Kwet recording, 11 December 1996, 22:30h, 22.5 ${ }^{\circ} \mathrm{C}$, unvouchered, recorded by Axel Kwet, 10 calls. Frog 2 - A. Kwet recording, 27 January 2001, 22:00h, $25.5^{\circ} \mathrm{C}$, unvouchered, recorded by Axel Kwet, 10 calls.

Brazil: Rio Grande do Sul; Guaíba, 30 06'S, $51^{\circ} 19^{\prime}$ W. A. Kwet recording, 8 December 1997, 03:50h, $21^{\circ} \mathrm{C}$, unvouchered, recorded by Axel Kwet, 3 calls.

Brazil: Rio Grande do Sul; Rio Pardinho, $29^{\circ} 36^{\prime} \mathrm{S}, 52^{\circ} 30^{\prime} \mathrm{W}$. A. Kwet recording, 30 January $2001,24: 00 \mathrm{~h}, 23^{\circ} \mathrm{C}$, unvouchered, recorded by Axel Kwet, 10 calls.

Brazil: Rio Grande do Sul; São Jerônimo, $29^{\circ} 58^{\prime}$ 'S, $51^{\circ} 43^{\prime}$ W. A. Kwet recording, 13 December $1998,22: 00 \mathrm{~h}, 23.5^{\circ} \mathrm{C}$, unvouchered, recorded by A. Kwet, 2 calls.

Brazil: Roraima; Boa Vista, $2^{\circ} 49^{\prime} \mathrm{N}, 60^{\circ} 40^{\prime} \mathrm{W}$. USNM recording 184 , cut $2,21: 20 \mathrm{~h}, 26.6^{\circ} \mathrm{C}$, voucher USNM 302098, recorded by Ronald I. Crombie, 10 calls.

Brazil: São Paulo; Boracéia, 233' S, $45^{\circ} 50^{\prime} \mathrm{W}$. USNM recording 24 , cut $15,22: 30 \mathrm{~h}$, $20-21^{\circ} \mathrm{C}$, voucher USNM 243685, recorded by A. Stanley Rand in captivity the same night of capture, 3 calls.

Bolivia: Beni; Estación Biologica del Beni, El Porvenir, $14^{\circ} 38^{\prime}$ S, $66^{\circ} 18^{\prime}$ W. Frog 1 - USNM recording 280, cut 17, 30 November 1990, 20:23h, $29^{\circ} \mathrm{C}$, voucher USNM 498292, recorded by George Middendorf, 10 calls. Frog 2 - USNM recording 280 , cut 18,30 November $1990,20: 37 \mathrm{~h}, 29^{\circ} \mathrm{C}$, voucher USNM 498290, recorded by George Middendorf, 10 calls. Frog 3 - USNM recording 280, cut 19, 30 November 1990, 21:06h, $29^{\circ} \mathrm{C}$, voucher USNM 498291, recorded by George Middendorf, 10 calls.

Bolivia: Beni; Estación Biologica del Beni, $14^{\circ} 30^{\prime}$ 'S, 66 $6^{\circ} 0^{\prime} \mathrm{W}$. Frog 1 - S. Reichle recording, December 1994, time of recording not indicated, $24.5^{\circ} \mathrm{C}$, unvouchered, recorded by Steffen Reichle, 10 calls. Frog 2 - S. Reichle recording, 6 November 1994, time of recording not indicated, $26^{\circ} \mathrm{C}$, unvouchered, recorded by Steffen Reichle, 10 calls.

Bolivia: Santa Cruz; Santa Cruz de la Sierra, $17^{\circ} 48^{\prime}$ S, $63^{\circ} 10^{\prime}$ W. J. Köhler recording, 31 January 1998, 20:30h, $25.7^{\circ} \mathrm{C}$, unvouchered, recorded by Jörn Köhler, 10 calls.

Bolivia: Santa Cruz; Santa Rosa de la Roca, $16^{\circ} 4^{\prime}$ 'S, $61^{\circ} 32^{\prime}$ 'W. J. Köhler recording, 18 October 1994, 19:00h, $25.5^{\circ} \mathrm{C}$, unvouchered, recorded by Jörn Köhler, 10 calls.

Bolivia: Santa Cruz; $159 \mathrm{~km}$ north of Santa Rosa de la Roca, inselberg locality, 143'' S, 6130'W. J. Köhler recording, 20 October 1994, 20:00h, $29.5^{\circ} \mathrm{C}$, unvouchered, recorded by Jörn Köhler, 10 calls.

Bolivia: Santa Cruz; $169 \mathrm{~km}$ north of Santa

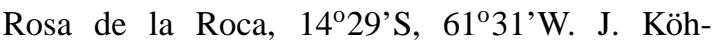
ler recording, 17 October 1994, time of recording not indicated, $29^{\circ} \mathrm{C}$, unvouchered, recorded by Jörn Köhler, 10 calls.

Paraguay: Itapua; El Tirol, near Encarnacion, $27^{\circ} 11^{\prime}$ S, 55 $5^{\circ} 43^{\prime} \mathrm{W}$. Frog 1 - USNM recording 178, cut 6,30 October $1980,20: 15 \mathrm{~h}, 17^{\circ} \mathrm{C}$, unvouchered, recorded by Mercedes S. Foster, 10 calls. Frog 2 USNM recording 178 , cut 7,30 October 1980 , time of recording not indicated, $17^{\circ} \mathrm{C}$, voucher USNM 253413, recorded by Mercedes S. Foster, 10 calls.

Argentina: Misiones; Parque Nacional Iguazú, $25^{\circ} 41^{\prime}$ 'S, 5426'W. Commercial recording, 'Voces de Anfibios Argentinos I', by Roberto Straneck, 
9 November $1988,20: 15 \mathrm{~h}, 22^{\circ} \mathrm{C}$, voucher MACN 33461, recorded by Miguel Castelino, 10 calls.

Argentina: Salta; Embarcación, 2313's, 64ㅇ' 'W. USNM recording 19, cut 4, 23 December $1971,22: 15 \mathrm{~h}, 21.3^{\circ} \mathrm{C}$, unvouchered, recorded by W. Ronald Heyer, 10 calls.

\section{ACKNOWLEDGMENTS}

We thank I. De la Riva, M.S. Hoogmoed, J. Köhler, A. Kwet, R. Márquez, G. Middendorf, A.S. Rand, M. Read, and S. Reichle for providing copies of their recordings. R. Chapman calculated the standardization of quantitative call parameters to $25^{\circ} \mathrm{C}$. A. Wynn produced Figure 1. A.S. Rand constructively reviewed developing versions of the manuscript. R.O. de Sá provided an insightful comment on an intermediate manuscript draft. P.E. Vanzolini translated the abstract. Research for this paper was supported by the Research Training Program, National Museum of Natural History (NMNH), Smithsonian Institution (SI) (YRR), the Neotropical Lowlands Research Program, NMNH, SI (R. Vari, Principal Investigator, WRH), and National Science Foundation Award 9815787 (to R. de Sá and WRH).

\section{RESUMO}

A rã Leptodactylus fuscus é encontrada na maior parte da América do Sul em formações abertas ou em ambientes perturbados. Estudos anteriores de diferenciação genética mostraram ausência de fluxo gênico entre unidades populacionais, o que é compatível com a existência de diversas espécies em vez de uma única. Examinamos a vocalização de anúncio de L. fuscus com a finalidade de verificar se variações na vocalização coincidiam com a diferenciação genética. Foram analisadas vocalizações de 32 indivíduos provenientes de 25 localidades distribuídas em toda a área de distribuição da espécie. Embora exista variação geográfica na vocalização, essa diversificação não corresponde à diferenciação genética ou à distância geográfica; as diferenças observadas são menores que aquelas tipicamente encontradas entre espécies aparentadas de Leptodactylus. O presente estudo é um exemplo de um padrão evolutivo raro, em que acentuada diferenciação genética não é acompanhada por diferenças marcantes nas vocalizações específicas. A freqüência relativamente baixa deste padrão, como usualmente entendido, pode refletir apenas falta de análises detalhadas de diferenciação acústica e genética dentro de sistemas populacionais correntemente considerados como espécies únicas de ampla distribuição geográfica.

Palavras-chave: Amphibia, Anura, Leptodactylus fuscus, vocalização de anúncio, especiação.

\section{REFERENCES}

AnONymous. 2000. Linear models. In: Systat 10. Statistics I. Chicago: SPSS Inc., p. I-365-I-398.

BARber PH. 1999a. Phylogeography of the canyon treefrog, Hyla arenicolor (Cope) based on mitochondrial DNA sequence data. Mol Ecol 8: 547-562.

Barber PH. 1999b. Patterns of gene flow and population genetic structure in the canyon treefrog, Hyla arenicolor (Cope). Mol Ecol 8: 563-576.

Blair WF and Littlejohn MJ. 1960. Stage of speciation of two allopatric populations of chorus frogs (Pseudacris). Evolution 14: 82-87.

Charif RA, Mitchell S And Clark CW. 1995. Canary 1.2 user's manual. Ithaca, NY: Cornell Laboratory of Ornithology, 1995. 229p.

Davies NB and Halliday TR. 1978. Deep croaks and fighting assessment in toads Bufo bufo. Nature 274: 683-685.

Driscoll DA. 1998. Genetic structure of the frogs Geocrinia lutea and Geocrinia rosea reflects extreme population divergence and range changes, not dispersal barriers. Evolution 52: 1147-1157.

Duellman WE and Trueb L. 1986. Biology of amphibians. New York: McGraw-Hill Book Co., 1986. $670 \mathrm{p}$.

Fritzsch B, Ryan MJ, Wilczynski W, HetheringTON WTE AND Walkowiak W. (Eds.). 1988. The evolution of the amphibian auditory system. New York: John Wiley \& Sons, 1988. 705p.

GerhardT HC. 1988. Acoustic properties used in call recognition by frogs and toads. In: FrITZSCH BM. ET AL. (Eds.), The evolution of the amphibian auditory system. New York: John Wiley \& Sons, p. 455-483.

GerhardT HC. 1994. The evolution of vocalization in 
frogs and toads. Annu Rev Ecol Syst 25: 293-324.

Gerhardt HC and Schwartz JJ. 2001. Auditory tuning and frequency preferences in anurans. In: RYAN MJ (Ed.), Anuran communication. Washington and London: Smithsonian Institution Press, p. 73-85.

Giacoma C and Castellano S. 2001. Advertisement call variation and speciation in the Bufo viridis complex. In: RyAN MJ (Ed.), Anuran communication. Washington and London: Smithsonian Institution Press, p. 205-219.

HEYER WR. 1978. Systematics of the fuscus group of the frog genus Leptodactylus (Amphibia, Leptodactylidae). Nat Hist Mus Los Angeles County Sci Bull 29: $1-85$.

Heyer Wr, Rand AS, Cruz CAG, Peixoto OL and Nelson CE. 1990. Frogs of Boracéia. Arq Zool 31: 231-410.

Heyer WR, García-Lopez JM and Cardoso AJ. 1996. Advertisement call variation in the Leptodactylus mystaceus species complex (Amphibia: Leptodactylidae) with a description of a new sibling species. Amphibia-Reptilia 17: 7-31.

Leviton AE, Gibbs Jr RH, Heal E and Dawson CE. 1985. Standards in herpetology and ichthyology: Part I. Standard symbolic codes for institutional resource collections in herpetology and ichthyology. Copeia 1985: 802-832.

LitTLEJOHN MJ. 1988. Frog calls and speciation: The retrograde evolution of homogamic acoustic signaling systems in hybrid zones. In: FrITZSCH B ET AL. (Eds.), The evolution of the amphibian auditory system. New York: John Wiley \& Sons, 1988, p. 613-635.

LitTlejohn MJ. 2001. Patterns of differentiation in temporal properties of acoustic signals of anurans. In: RyAn MJ (Ed.), Anuran communication. Washington and London: Smithsonian Institution Press, p. 102-120.

Manz R. 1975. Die Fusionsfrequenzen der Kehlkopfmuskeln und eines Beinmuskels in Abhängigkeit von der Temperatur bei europäischen Froschlurchen (Anura). Zool Jb Physiol 79: 221-245.

Roberts JD And Wardell-Johnson G. 1995. Call differences between peripheral isolates of the Geocrinia rosea complex (Anura: Myobatrachidae) in south- western Australia. Copeia 1995: 899-906.

RoHLF FJ. 1998. NTSYSpc. Numerical taxonomy and multivariate analysis system. Version 2.0. User guide. Setauket, New York: Exeter Software, 1998. $31 \mathrm{p}$.

RYAN MJ. 1980. Female mate choice in a Neotropical frog. Science 209: 523-525.

RyAn MJ. 1985. The túngara frog. A study in sexual selection and communication. Chicago and London: The University of Chicago Press, 1985. 230p.

Ryan MJ, Rand AS and Weigt LA. 1996. Allozyme and advertisement call variation in the túngara frog, Physalaemus pustulosus. Evolution 50: 2435-2453.

Toda M, Matsui M, Nishida M and Ota H. 1998. Genetic divergence among Southeast and East Asian populations of Rana limnocharis (Amphibia: Anura), with special reference to sympatric cryptic species in Java. Zool Sci 15: 607-613.

Walkowiak W. 1988. Central temporal encoding. In: Fritzsch B. ET AL. (Eds.), The evolution of the amphibian auditory system. New York: John Wiley \& Sons, p. 275-294.

WiLKINSON L. 2000. Multidimensional scaling. In: SYSTAT 10. Statistics II. Chicago: SPSS Inc., p. II-119-II-145.

Wilkinson L, Engelman L and Marcantonio R. 2000. Correlations, similarities, and distance measures. In: SYSTAT 10. Statistics I. Chicago: SPSS Inc, p. I-115-I-146.

Wynn A And Heyer WR. 2001. Do geographically widespread species of tropical amphibians exist? An estimate of genetic relatedness within the neotropical frog Leptodactylus fuscus (Schneider 1799) (Anura Leptodactylidae). Trop Zool 14: 255-285.

ZaKon HH AND WilcZYNSKI W. 1988. The physiology of the anuran eighth nerve. In: Fritzsch B ET AL. (Eds.), The evolution of the amphibian auditory system. New York: John Wiley \& Sons, p. 125-155.

ZweIFEL RG. 1968. Effects of temperature, body size, and hybridization on mating calls of toads, Bufo a. americanus and Bufo woodhousii fowleri. Copeia 1968: 269-285. 